\title{
Esthetic restorative materials and glass ionomer cements: Influence of acidic drink exposure on bacterial adhesion
}

\author{
Claudio Poggio ${ }^{1}$, Lodovico Vialba ${ }^{1}$, Riccardo Marchioni ${ }^{1}$, Marco Colombo ${ }^{1}$, \\ Giampiero Pietrocola ${ }^{2}$
}

Correspondence: Dr. Claudio Poggio

Email: claudio.poggio@unipv.it
'Department of Clinical-Surgical, Diagnostic and Pediatric Sciences, Section of Dentistry, University of Pavia, Pavia, Italy,

2Department of Molecular Medicine, Unit of

Biochemistry, University of Pavia, Pavia, Italy

\section{ABSTRACT}

Objective: The purpose of this research was to evaluate and compare bacterial adhesion on five esthetic restorative materials, three glass ionomer cements (GIC), and two GIC with coat. All the materials were considered after acidic drink exposure. Materials and Methods: Thirty cylindrical sample of each of the 10 materials were prepared and then divided into three groups: group 1 (baseline), Group 2 ( 1 day in acidic soft drink), and Group 3 (7 days in acidic soft drink). Bacterial suspension of Streptococcus mutans was cultured and deposited onto each material, and the adhesion was evaluated through the colony-forming units determination. One-way ANOVA and Bonferroni's post hoc tests were applied to estimate significant differences between the esthetic materials. Results: The highest amount of S. mutans was recorded in Group 3 and the lowest in Group 1 (baseline). In general, the GIC showed bacterial adhesion values higher than the ones related to composites both in Group 2 than in Group 3. Acidic soft drinks lead a time-dependent degradation of restorative materials causing an increase of the surface rugosity. In fact, a general increase in S. mutans cells adhesion to treated samples was observed. Conclusions: The use of acidic soft drink resulted in a degradation of the surface layer of the restorative material with consequent increase of bacterial adhesion. The GIC can be considered a more friendly environment for bacterial adhesion. This is true in particular if acid substances have already deteriorated the surface.

Key words: Acidic drinks, esthetic restorative materials, glass ionomer cement, Streptococcus mutans

\section{INTRODUCTION}

The use of resins-based materials for direct and indirect restorations has now entered the daily clinical practice; parallel to restorative composite resins, only for direct restorations, glass ionomer cements (GIC) are used for their self-adhesive capacity and antibacterial ability. ${ }^{[1-4]}$

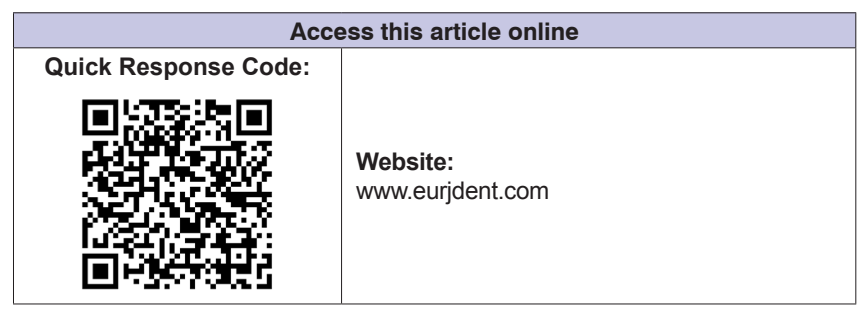

One of the problems concerning adhesive restorative procedures is represented by the secondary infiltration of the restoration. This is due to the presence of a marginal gap between the filling and the tooth surface. This occurrence is more frequent

This is an open access journal, and articles are distributed under the terms of the Creative Commons Attribution-NonCommercial-ShareAlike 4.0 License, which allows others to remix, tweak, and build upon the work non-commercially, as long as appropriate credit is given and the new creations are licensed under the identical terms.

For reprints contact: reprints@medknow.com

How to cite this article: Poggio C, Vialba L, Marchioni R, Colombo M, Pietrocola G. Esthetic restorative materials and glass ionomer cements: Influence of acidic drink exposure on bacterial adhesion. Eur J Dent 2018;12:204-9.

DOI: 10.4103/ejd.ejd_219_17 
among GIC. Moreover, it is one of the most likely causes of resurfacing of previous fillings. ${ }^{[5,6]}$ One of the biggest problems for these materials is the marked susceptibility to the accumulation of bacterial plaque. ${ }^{[7,8]}$ In the execution of direct restorations, due to the shrinkage stress of polymerization, it is possible the genesis of marginal discrepancies in which the cariogenic bacteria contained in plaque can give rise to a secondary infiltration. ${ }^{[9,10]}$ An increase in plaque retention places patients at risk for secondary caries adjacent to the composite resin margins, and additionally, the formation of biofilm may result in gingival inflammation. ${ }^{[11]}$ For indirect restorations, this issue, even if present, is limited to the cement adhesive layer.

The strong tendency to accumulate plaque for composite materials thus plays a central role in the formation of secondary caries. ${ }^{[12,13]}$ The formation of oral plaque on the surface of restorative materials, and in general on the surface of the teeth, is a complex process that is determined both by the salivary and bacterial conditions of the oral cavity, but also by the eating habits and the surface on which it is formed. ${ }^{[14,15]}$ Moreover, common acidic beverages (cola, energy drinks) can produce erosion of restorative materials. ${ }^{[16]}$ The distribution and form of the fillers, the composition of the resin matrix, and the silane surface treatment of the filler particles significantly affect the surface degradation of the composite materials. ${ }^{[17]}$ Composites are complex heterogeneous materials formed from a resin base in which are embedded the filler particles, coated with a bonding agent, of different origin with variable size and shape. This implies that the surface of such materials can be a heterogeneous interface of particles distributed on different physical-chemical phases: commercially, available restorative composite resins will present different surfaces in terms of roughness and polishing depending on the filler used..$^{[18-21]}$ At the same way, GIC are heterogeneous in terms of formulation, and in addition, the release of fluoride ions causes a further deterioration of the surface that over time will facilitate the adhesion of bacterial plaque. ${ }^{[1]}$ However, GIC are generally used where additional protection against tooth decay is required, especially in children, since potentially reduce microleakage adhering to tooth structure, inhibit the growth of cariogenic bacteria, and neutralize the acids produced by these bacteria by releasing ions. ${ }^{[22,23]}$ The surface morphology of the restoration therefore plays a crucial role in adherence of bacterial plaque, both for composite resins and GIC. ${ }^{[24-26]}$
The purpose of this research was to evaluate and compare bacterial adhesion on five esthetic restorative materials and three GIC after acidic drink exposure. The null hypothesis of the study was that there is no significant difference in bacterial adhesion values among the different restorative materials after exposure to acidic drink.

\section{MATERIALS AND METHODS}

\section{Specimens' preparation}

Five esthetic restorative materials and three GIC were evaluated in this study [Table 1].

Materials were polymerized into silicon rings (external diameter $9 \mathrm{~mm}$, internal diameter $6 \mathrm{~mm}$, thick $2 \mathrm{~mm}$ ) to obtain identical specimens. ${ }^{[2]}$ Cavities of these rings were slightly overfilled with material, covered with Mylar Matrix Strip (Henry Schein, Melville, NY, USA), pressed between two glass plates and polymerized for $40 \mathrm{~s}$ on each side using a curing unit (Celalux II, Voco, Cuxhaven, Germany). One light polymerization mode was used for each material standard: $1000 \mathrm{~mW} / \mathrm{cm}^{2}$ for $40 \mathrm{~s}$. The light was placed perpendicular to the specimen surface, at distance of $1.5 \mathrm{~mm}$ or less. ${ }^{[27]}$ The upper surface of each specimen was then polished

\begin{tabular}{|c|c|c|c|}
\hline Material & Manufacturer & Type & LOT \\
\hline $\begin{array}{l}\text { Filtek } \\
\text { Supreme } \\
\text { XTE }\end{array}$ & $\begin{array}{l}\text { 3M ESPE, St } \\
\text { Paul, MN, USA }\end{array}$ & $\begin{array}{l}\text { Nanofilled } \\
\text { composite }\end{array}$ & N801824 \\
\hline $\begin{array}{l}\text { Ceram.X } \\
\text { Universal }\end{array}$ & $\begin{array}{l}\text { Dentsply De } \\
\text { Trey, Konstanz, } \\
\text { Germany }\end{array}$ & $\begin{array}{l}\text { Nanohybrid } \\
\text { composite with } \\
\text { prepolymerized } \\
\text { fillers }\end{array}$ & 1608000937 \\
\hline Essentia & $\begin{array}{l}\text { GC Corporation, } \\
\text { Tokyo, Japan }\end{array}$ & $\begin{array}{l}\text { Microfilled hybrid } \\
\text { composite }\end{array}$ & 1601121 \\
\hline $\begin{array}{l}\text { Admira } \\
\text { Fusion }\end{array}$ & $\begin{array}{l}\text { Voco, Cuxhaven, } \\
\text { Germany }\end{array}$ & $\begin{array}{l}\text { Nanohybrid } \\
\text { ormocer-based } \\
\text { composite }\end{array}$ & 1630296 \\
\hline $\begin{array}{l}\text { Estelite } \\
\text { Asteria }\end{array}$ & $\begin{array}{l}\text { Tokuyama Dental } \\
\text { Corporation, } \\
\text { Tokyo, Japan }\end{array}$ & $\begin{array}{l}\text { Supranano } \\
\text { spherical hybrid } \\
\text { composite }\end{array}$ & 066E16 \\
\hline $\begin{array}{l}\text { ChemFil } \\
\text { Rock }\end{array}$ & $\begin{array}{l}\text { Dentsply De } \\
\text { Trey, Konstanz, } \\
\text { Germany }\end{array}$ & Glass ionomer & 1607000503 \\
\hline $\begin{array}{l}\text { Equia } \\
\text { Forte Fil }\end{array}$ & $\begin{array}{l}\text { GC Corporation, } \\
\text { Tokyo, Japan }\end{array}$ & Glass ionomer & $150810 \mathrm{~A}$ \\
\hline $\begin{array}{l}\text { lonoStar } \\
\text { Plus }\end{array}$ & $\begin{array}{l}\text { Voco, Cuxhaven, } \\
\text { Germany }\end{array}$ & Glass ionomer & 1631408 \\
\hline $\begin{array}{l}\text { Equia Forte } \\
\text { Fil + Equia } \\
\text { Forte Coat }\end{array}$ & $\begin{array}{l}\text { GC Corporation, } \\
\text { Tokyo, Japan }\end{array}$ & $\begin{array}{l}\text { Glass ionomer } \\
+ \text { multifunctional } \\
\text { monomer coating }\end{array}$ & $150810 \mathrm{~A}$ \\
\hline $\begin{array}{l}\text { lonoStar } \\
\text { Plus + Easy } \\
\text { Glaze }\end{array}$ & $\begin{array}{l}\text { Voco, Cuxhaven, } \\
\text { Germany }\end{array}$ & $\begin{array}{l}\text { Glass ionomer }+ \\
\text { nano-filled coating }\end{array}$ & 1631408 \\
\hline
\end{tabular}


with fine and superfine polishing disks (Sof-Lex Pop On; 3M ESPE, St. Paul, MN, USA) to simulate clinical conditions.

Thirty cylindrical specimens of each material were prepared in this manner. After polymerization and during the experimentation, the specimens were stored in distilled water at $37^{\circ} \mathrm{C}$ and $100 \%$ humidity. Each material was tested 4 weeks after polymerization.

\section{Immersion in acidic drink}

Each material is represented by 30 specimens. The 30 specimens of each esthetic restorative materials were randomly attributed to three groups $(n=10)$ : specimens of Group 1 were used as control, specimens of Group 2 were immersed in $50 \mathrm{ml}$ of acidic drink (Coca Cola/Coca Cola Company, Milano, Italy) for 1 day, and specimens of Group 3 were immersed in $50 \mathrm{ml}$ of acidic drink (Coca Cola/Coca Cola Company, Milano, Italy) for 7 days. The specimen of the given material pertaining to a specific group was removed from the beverage using tweezers, sterilized in autoclave at $121^{\circ} \mathrm{C}$ and packed in dry plastic sterile bags before being tested with bacteria. ${ }^{[27,28]}$

\section{Bacterial growth condition}

A strain of Streptococcus mutans (CCUG35176) obtained from the culture collection of the University of Göteborg was used for the in vitro adhesion tests. S. mutans was cultured in Brain Heart Infusion (BHI, Difco, CA, USA) supplemented with $10 \%(\mathrm{v} / \mathrm{v})$ heat-inactivated horse blood serum (Oxoid, Milan, Italy) to improve its growth. The culture of S. mutans was statically incubated under aerobic conditions for $16 \mathrm{~h}$ at $37^{\circ} \mathrm{C}$. This culture, used as source for the experiments, was reduced at a final density of $1 \times 10^{10} \mathrm{cells} / \mathrm{mL}$ as determined by comparing the OD600 of the sample with a standard curve relating OD600 to cell number. ${ }^{[29]}$

\section{Assessment of bacterial adhesion}

After extensive washing of each materials, $100 \mu \mathrm{L}$ of an overnight growth culture $\left(10^{7}\right.$ bacteria $\left./ \mathrm{mL}\right)$ was seeded onto each sample test placed at the bottom of a 24-well plate (Celbio, Milan, Italy) and incubated at $37^{\circ} \mathrm{C}$ for $4 \mathrm{~h}$ in static conditions. The choice of this time of incubation is due to the fact that biofilm formation in the oral cavity normally occurs in 2-4 h. After incubation, loosely adhering bacteria were removed by gently washing the samples tests with PBS. Three sample tests of each experimental condition were used for total viable count (TVC). Briefly, the samples with bacterial cells were dispersed into $1 \mathrm{~mL}$ sterile Ringer solution (Oxoid, Milan, Italy) by vortex for 3 min. ${ }^{[10]}$
Serial dilutions of the bacterial cells suspensions were prepared, and $0.1 \mathrm{~mL}$ of each dilution was deposited onto BHI agar (Bacto agar, Difco, CA, USA) plates. The plates were incubated for $24-48 \mathrm{~h}$ at $37^{\circ} \mathrm{C}$ and the number of colonies counted. Mean TVC values were calculated for each sample, and the results are expressed as colony-forming units (CFU) per mL. ${ }^{[30]}$

\section{Statistical analysis}

First, data were assessed to be normal by means of Shapiro-Wilk normality test. The analysis of variance (differences among substrates at each condition and differences about treatment, per substrate) was carried out using two-way ANOVA followed by Bonferroni's post hoc tests. Analyses were performed using Prism 4.0 (GraphPad Software, La Jolla, CA, USA). Two-tailed $P=0.05$ were considered statistically significant.

\section{RESULTS}

To evaluate the $S$. mutans ability to adhere to different restorative materials with or without soft drink treatment, a TVC assay was performed. The results are shown in Table 2 and collectively represented in Figure 1.

\begin{tabular}{|c|c|c|c|}
\hline \multirow[t]{2}{*}{ Material } & \multicolumn{3}{|c|}{ Mean of bacterial adhesion \pm SD } \\
\hline & Control & $\begin{array}{l}\text { After } 1 \text { day in } \\
\text { soft drink }\end{array}$ & $\begin{array}{l}\text { After } 1 \text { week in } \\
\text { soft drink }\end{array}$ \\
\hline $\begin{array}{l}\text { Filtek } \\
\text { Supreme } \\
\text { XTE }\end{array}$ & $1.50 \pm 0.70 \times 10^{2}$ & $3.450 \pm 0.21 \times 10^{3}$ & $2.0325 \pm 0.75 \times 10^{4}$ \\
\hline $\begin{array}{l}\text { Ceram.X } \\
\text { Universal }\end{array}$ & $1.075 \pm 0.74 \times 10^{3}$ & $2.625 \pm 0.41 \times 10^{3}$ & $1.7425 \pm 0.26 \times 10^{4}$ \\
\hline Essentia & $4.050 \pm 0.14 \times 10^{3 \S}$ & $5.175 \pm 0.32 \times 10^{3 \S}$ & $1.3800 \pm 0.64 \times 10^{4}$ \\
\hline $\begin{array}{l}\text { Admira } \\
\text { Fusion }\end{array}$ & $1.50 \pm 0.42 \times 10^{2}$ & $4.075 \pm 0.46 \times 10^{3}$ & $1.1200 \pm 0.58 \times 10^{4}$ \\
\hline $\begin{array}{l}\text { Estelite } \\
\text { Asteria }\end{array}$ & $5.50 \pm 0.31 \times 10^{2}$ & $8.300 \pm 0.60 \times 10^{3 \S}$ & $1.2600 \pm 0.78 \times 10^{4 \S}$ \\
\hline $\begin{array}{l}\text { ChemFil } \\
\text { Rock }\end{array}$ & $2.550 \pm 0.35 \times 10^{3}$ & $2.5375 \pm 0.45 \times 10^{4 \S}$ & $1.9925 \pm 0.24 \times 10^{4 \S}$ \\
\hline $\begin{array}{l}\text { Equia } \\
\text { Forte Fil }\end{array}$ & $4.825 \pm 0.51 \times 10^{3}$ & $1.3325 \pm 0.67 \times 10^{4}$ & $4.1750 \pm 0.87 \times 10^{4}$ \\
\hline $\begin{array}{l}\text { Iono Star } \\
\text { Plus }\end{array}$ & $3.225 \pm 0.84 \times 10^{3}$ & $1.8400 \pm 0.41 \times 10^{4 \S}$ & $1.3725 \pm 0.53 \times 10^{4 \S}$ \\
\hline $\begin{array}{l}\text { Equia Forte } \\
\text { Fil + Equia } \\
\text { Forte Coat }\end{array}$ & $1.00 \pm 0.23 \times 10^{2}$ & $2.2075 \pm 0.75 \times 10^{4 \S}$ & $2.3125 \pm 0.75 \times 10^{4 \S}$ \\
\hline $\begin{array}{l}\text { IonoStar } \\
\text { Plus + Easy } \\
\text { Glaze }\end{array}$ & $1.100 \pm 0.49 \times 10^{3}$ & $4.275 \pm 0.36 \times 10^{3}$ & $1.4800 \pm 0.34 \times 10^{4}$ \\
\hline
\end{tabular}

European Journal of Dentistry, Volume 12 / Issue 2 / April-June 2018 


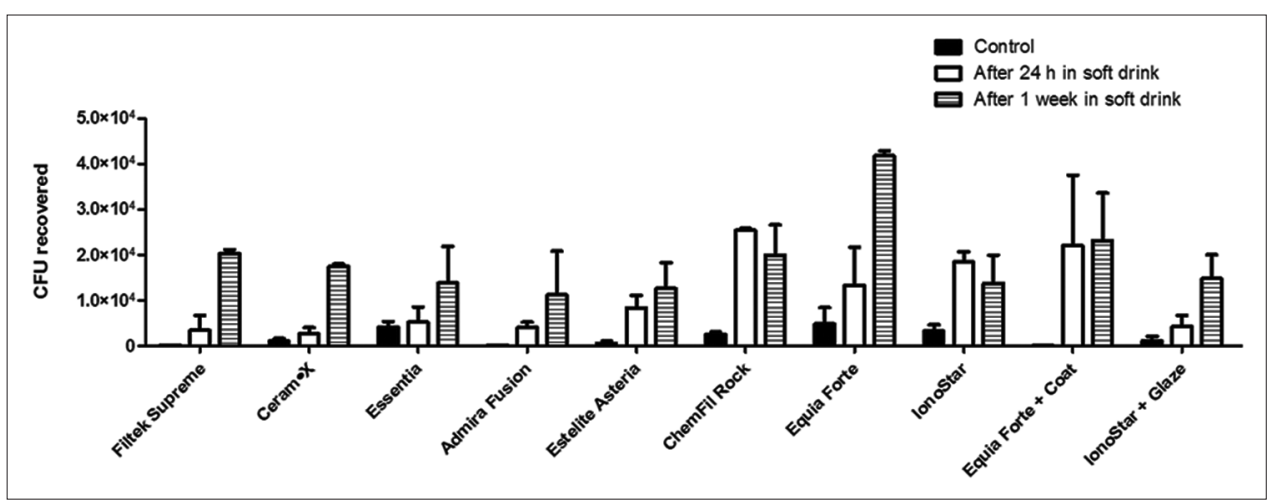

Figure 1: Colony-forming units values of Streptococcus mutans cells adherent to restorative materials. Results were expressed as colony-forming units/mL

The bacterial adherence values to the untreated materials (the control) are ranging from $10^{2}$ to $5 \times 10^{3} \mathrm{CFU}$. Filtek Supreme XTE, Admira Fusion, and Equia Forte Fil + Equia Forte Coat exhibited the lowest bacterial adhesion values, whereas the CFU values for CeramX, Estelite Asteriam and Iono Star + coat were statistically significant $(P<0.05)$ and higher than the materials above mentioned. The highest bacterial adhesion values were showed for Essentia, ChemFil Rock, Equia Forte Fil, and IonoStar Plus $(P<0.05)$.

An increase in S. mutans cells adhesion to Coca Cola-treated samples was observed. Moreover, the treatment of Filtek Supreme XTE, Ceram $\bullet X$ Universal, Essentia, Admira Fusion, Equia Forte Fil, and IonoStar Plus + coat with acidic drink for long time (7 days) increases their susceptibility to be colonized compared to the same samples treated for a shorter time $(24 \mathrm{~h})(P<0.05)$. After $24 \mathrm{~h}$ acidic drink treatment, Filtek Supreme XTE, Ceram $\bullet X$ Universal, Essentia, Admira Fusion, and IonoStar Plus + IonoStar Plus Coat showed the lowest values of bacterial adhesiveness (ranging from 2625 to $\left.5175 \times 10^{3} \mathrm{CFU}\right)(P<0.05)$, without differences among themselves $(P>0.05)$. Instead, Estelite Asteria, ChemFil Rock, Equia Forte Fil, IonoStar Plus, and Equia Forte Fil + Equia Forte Coat showed the highest values (from 083 to $\left.253 \times 10^{4} \mathrm{CFU}\right)(P<0.05)$, without differences among themselves $(P>0.05)$. No significant difference between samples treated for 7 days with acidic drink was observed $(P>0.05)$.

\section{DISCUSSION AND CONCLUSIONS}

Bacterial plaque is an aggregate of microorganism that adheres tenacely to each other and to the dental surfaces; it is a biofilm wrapped in an extracellular polymer matrix secreted by the bacterial flora of the oral cavity. After only few minutes of brushing, the teeth are covered with a film obtained from a layer of salivary mucoproteins that is rapidly colonized by the microorganisms present in the oral cavity: complex processes such as salivary pellicle formation, pellicle adsorption to the surface, passive transport of bacteria to the pellicle surface, coadhesion, and multiplication are the protagonists of oral plaque formation. ${ }^{[31]}$ Modern restorative materials appear less affine to bacterial biofilm, consequently reducing and delaying oral plaque formation. ${ }^{[10]}$

During the initial stages of colonization, quantitatively, the bacterial adhesion to the restorative materials is related to the intrinsic physicochemical properties of restorative materials; however, also, the types of bacteria present in the biofilm and the active and passive adhesion mechanisms affect the development of oral plaque. ${ }^{[32,33]}$ The growth and development of dental biofilm can be stimulated both in vivo and in vitro: to conduct the study analyzing simultaneously all the material in similar condition, it was decided to proceed by an in vitro research. ${ }^{[31]}$ An in vitro biofilm model allows to the use of aseptic and removable samples, which should be discrete, representative, and reproducible. Extended exposure to soft drink was used to deteriorate and alters the surface of the materials tested in this study and creates a more suitable substrate for the formation and adhesion of bacterial plaque; the use of acidic soft drink is served to mimic the aging process of restorative materials that inevitably occur in the oral environment: the result is a degradation of the surface layer of the restorative material with consequent creation of a rougher surface.

Regarding the glass-ionomer group, no significant reduction in bacterial adhesion was recorded, even though they are known for their significant release of fluoride. On the contrary, all the GIC of the 
study appeared as the most adhesive surfaces. This behavior can be explained by the reduced contact time between bacteria and GIC. As investigated in other studies, the fluoride released by these materials requires a variable time span (from $48 \mathrm{~h}$ to 7 days) to correctly express its antibacterial activity. ${ }^{[3,34]}$ The objective of this in vitro study was to evaluate and compare bacterial adhesion in relation to the different types of materials and the timing of exposure of such materials to acidic drink. The results of this investigation suggest that surface morphology and roughness of restorative materials is critical for bacterial adhesion and a correlation can be established. In Group 1, differences among materials were recorded. the highest values were recorded for GIC that appear to be rougher than composites. ${ }^{[35]}$ The use of coat reduces adhesion values in the control group, but the action of acids alters its surface very quickly, raising the values of adhesion to the amount of the other materials in Groups 2 and 3. All materials have demonstrated a statistically significant increase in terms of bacterial adhesion after exposure to acidic drink, which in most cases increases with exposure to harmful factor. Within the limits of the present in vitro study, bacterial adhesion seems to be related to erosion of restorative materials caused by acids.

\section{Financial support and sponsorship}

Nil.

\section{Conflicts of interest}

There are no conflicts of interest.

\section{REFERENCES}

1. Fúcio SB, Paula AB, Sardi JC, Duque C, Correr-Sobrinho L, Puppin-Rontani RM, et al. Streptococcus mutans biofilm influences on the antimicrobial properties of glass ionomer cements. Braz Dent J 2016;27:681-7.

2. Naik RG, Dodamani AS, Khairnar MR, Jadhav HC, Deshmukh MA. Comparative assessment of antibacterial activity of different glass ionomer cements on cariogenic bacteria. Restor Dent Endod 2016;41:278-82.

3. Wang SP, Ge Y, Zhou XD, Xu HH, Weir MD, Zhang KK, et al. Effect of anti-biofilm glass-ionomer cement on Streptococcus mutans biofilms. Int J Oral Sci 2016;8:76-83.

4. Rai N, Naik R, Gupta R, Shetty S, Singh A. Evaluating the effect of different conditioning agents on the shear bond strength of resin-modified glass ionomers. Contemp Clin Dent 2017;8:604-12.

5. Fan C, Chu L, Rawls HR, Norling BK, Cardenas HL, Whang K, et al. Development of an antimicrobial resin - A pilot study. Dent Mater 2011;27:322-8

6. Opdam NJ, van de Sande FH, Bronkhorst E, Cenci MS, Bottenberg P, Pallesen $\mathrm{U}$, et al. Longevity of posterior composite restorations: A systematic review and meta-analysis. J Dent Res 2014;93:943-9.

7. Beyth N, Domb AJ, Weiss EI. An in vitro quantitative antibacterial analysis of amalgam and composite resins. J Dent 2007;35:201-6.

8. de Alencar E Silva Leite ML, da Cunha Medeiros E Silva FD, Meireles SS, Duarte RM, Andrade AK. The effect of drinks on color stability and surface roughness of nanocomposites. Eur J Dent 2014;8:330-6.
9. Ceci M, Viola M, Rattalino D, Beltrami R, Colombo M, Poggio C, et al. Discoloration of different esthetic restorative materials: A spectrophotometric evaluation. Eur J Dent 2017;11:149-56.

10. Derchi G, Vano M, Barone A, Covani U, Diaspro A, Salerno M, et al. Bacterial adhesion on direct and indirect dental restorative composite resins: An in vitro study on a natural biofilm. J Prosthet Dent 2017;117:669-76.

11. Park JW, Song CW, Jung JH, Ahn SJ, Ferracane JL. The effects of surface roughness of composite resin on biofilm formation of Streptococcus mutans in the presence of saliva. Oper Dent 2012;37:532-9.

12. Deligeorgi V, Mjör IA, Wilson NH. An overview of reasons for the placement and replacement of restorations. Prim Dent Care 2001;8:5-11.

13. Xie D, Weng Y, Guo X, Zhao J, Gregory RL, Zheng C, et al. Preparation and evaluation of a novel glass-ionomer cement with antibacterial functions. Dent Mater 2011;27:487-96.

14. Busscher HJ, Bos R, van der Mei HC. Initial microbial adhesion is a determinant for the strength of biofilm adhesion. FEMS Microbiol Lett 1995;128:229-34.

15. Poggio C, Arciola CR, Rosti F, Scribante A, Saino E, Visai L, et al. Adhesion of Streptococcus mutans to different restorative materials. Int J Artif Organs 2009;32:671-7.

16. Erdemir U, Yildiz E, Eren MM, Ozel S. Surface hardness evaluation of different composite resin materials: Influence of sports and energy drinks immersion after a short-term period. J Appl Oral Sci 2013;21:124-31.

17. Poggio C, Dagna A, Chiesa M, Colombo M, Scribante A. Surface roughness of flowable resin composites eroded by acidic and alcoholic drinks. J Conserv Dent 2012;15:137-40.

18. Tuncer D, Karaman E, Firat E. Does the temperature of beverages affect the surface roughness, hardness, and color stability of a composite resin? Eur J Dent 2013;7:165-71.

19. Salerno M, Giacomelli L, Derchi G, Patra N, Diaspro A. Atomic force microscopy in vitro study of surface roughness and fractal character of a dental restoration composite after air-polishing. Biomed Eng Online 2010:9:59.

20. Talu S, Stach S, Alb SF, Salerno M. Multifractal characterization of a dental restorative composite after air-polishing. Chaos Solitons Fractals 2015;71:7-13.

21. Salerno M, Derchi G, Thorat S, Ceseracciu L, Ruffilli R, Barone AC, et al. Surface morphology and mechanical properties of new-generation flowable resin composites for dental restoration. Dent Mater 2011;27:1221-8.

22. FúcioSB, Carvalho FG, Sobrinho LC, Sinhoreti MA, Puppin-Rontani RM. The influence of 30-day-old Streptococcus mutans biofilm on the surface of esthetic restorative materials - An in vitro study. J Dent 2008;36:833-9.

23. Mitra SB, Lee CY, Bui HT, Tantbirojn D, Rusin RP. Long-term adhesion and mechanism of bonding of a paste-liquid resin-modified glass-ionomer. Dent Mater 2009;25:459-66.

24. Ikeda M, Matin K, Nikaido T, Foxton RM, Tagami J. Effect of surface characteristics on adherence of $S$. mutans biofilms to indirect resin composites. Dent Mater J 2007;26:915-23.

25. Alam F, Balani K. Adhesion force of Staphylococcus aureus on various biomaterial surfaces. J Mech Behav Biomed Mater 2017;65:872-80.

26. Yuan C, Wang X, Gao X, Chen F, Liang X, Li D, et al. Effects of surface properties of polymer-based restorative materials on early adhesion of Streptococcus mutans in vitro. J Dent 2016;54:33-40.

27. Ceci M, Rattalino D, Viola M, Beltrami R, Chiesa M, Colombo M, et al. Resin infiltrant for non-cavitated caries lesions: Evaluation of color stability. J Clin Exp Dent 2017;9:e231-e237.

28. Poggio C, Gulino C, Mirando M, Colombo M, Pietrocola G. Preventive effects of different protective agents on dentin erosion: An in vitro investigation. J Clin Exp Dent 2017;9:e7-e12.

29. Poggio C, Beltrami R, Colombo M, Ceci M, Dagna A, Chiesa M, et al. In vitro antibacterial activity of different pulp capping materials. J Clin Exp Dent 2015;7:e584-8.

30. Scavone M, Armentano I, Fortunati E, Cristofaro F, Mattioli S, Torre L, et al. Antimicrobial properties and cytocompatibility of PLGA/Ag nanocomposites. Materials (Basel) 2016;9. pii: E37.

31. Rolland SL, McCabe JF, Robinson C, Walls AW. In vitro biofilm formation on the surface of resin-based dentine adhesives. Eur J Oral Sci 2006;114:243-9.

32. Quirynen M. The clinical meaning of the surface roughness and the surface free energy of intra-oral hard substrata on the microbiology 


\section{Poggio, et al.: Bacterial adhesion on different restorative materials}

of the supra- and subgingival plaque: Results of in vitro and in vivo experiments. J Dent 1994;22 Suppl 1:S13-6.

33. Montanaro L, Campoccia D, Rizzi S, Donati ME, Breschi L, Prati C, et al. Evaluation of bacterial adhesion of Streptococcus mutans on dental restorative materials. Biomaterials 2004;25:4457-63.

34. Eick S, Glockmann E, Brandl B, Pfister W. Adherence of Streptococcus mutans to various restorative materials in a continuous flow system. J Oral Rehabil 2004;31:278-85.

35. Carvalho FG, Sampaio CS, Fucio SB, Carlo HL, Correr-Sobrinho L, Puppin-Rontani RM, et al. Effect of chemical and mechanical degradation on surface roughness of three glass ionomers and a nanofilled resin composite. Oper Dent 2012;37:509-17. 